Supplement of The Cryosphere, 12, 2109-2122, 2018

https://doi.org/10.5194/tc-12-2109-2018-supplement

(C) Author(s) 2018. This work is distributed under

the Creative Commons Attribution 4.0 License.

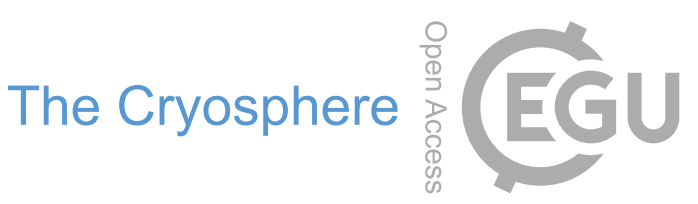

(c) (1)

Supplement of

\title{
Local topography increasingly influences the mass balance of a retreating cirque glacier
}

\section{Florentine et al.}

Correspondence to: Caitlyn Florentine (caitlyn.florentine@umontana.edu)

The copyright of individual parts of the supplement might differ from the CC BY 4.0 License. 


\section{Supplement contents:}

- Details on the glaciological mass balance calibration

- $\quad$ Figure S1

- $\quad$ Figure S2

$5 \quad$ - Figure S3

- Table S1

- Table S2

- $\quad$ Table S3 


\section{Glaciological mass balance calibration}

We defined the annual glaciological balance as the sum $\left(B_{\text {a.sum }}\right)$ of the site index summer $\left(B_{s}\right)$ and winter $\left(B_{w}\right)$ balances reported by Clark et al. (2017). We calibrated annual and summer balances using the following steps, defined in the calibration section of the Zemp et al. (2013) reanalysis procedure.

5 First, we calculated the centred glaciological balance $\left(\beta_{t}\right)$, which is the deviation from the mean glaciological balance $\left(\bar{B}_{\text {a.sum }}\right)$ for $2005-2014$. This term captured interannual variability documented by glaciological data:

$\beta_{t}=B_{a . s u m}-\bar{B}_{a . s u m}$

Next, we used this centered glaciological balance and the geodetic mass balance $\left(\bar{B}_{\text {a.geodetic }}\right)$ to calculate the calibrated annual balance $\left(B_{\text {a.cal }}\right)$ :

$10 \quad B_{\text {a.cal }}=\beta_{t}+\bar{B}_{\text {a.geodetic }}$

Finally, we calculated the calibrated summer balance:

$B_{\text {s.cal }}=B_{\text {a.cal }}-B_{w}$

These calibrated summer and annual balances are reported in Table 1. 

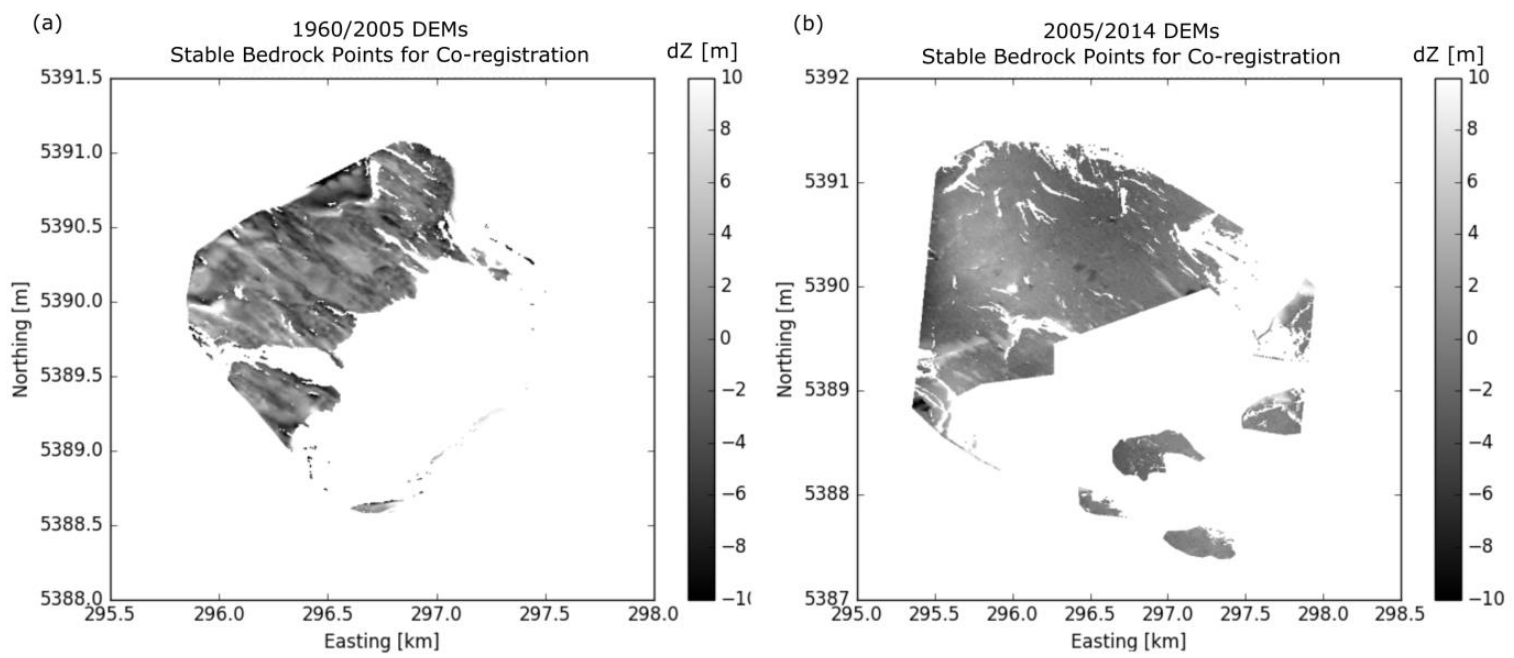

Figure S1: Elevation differences over the stable bedrock used for DEM co-registration are shown on a forced $-10 \mathrm{~m}$ to $10 \mathrm{~m}$ scale. The full suite of elevation differences over stable bedrock terrain is shown in Figure S2.

(a)

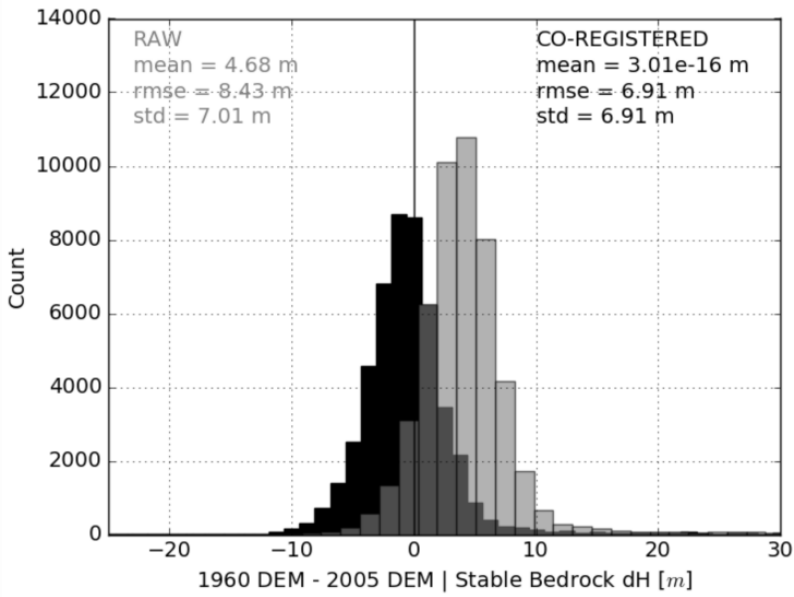

(b)

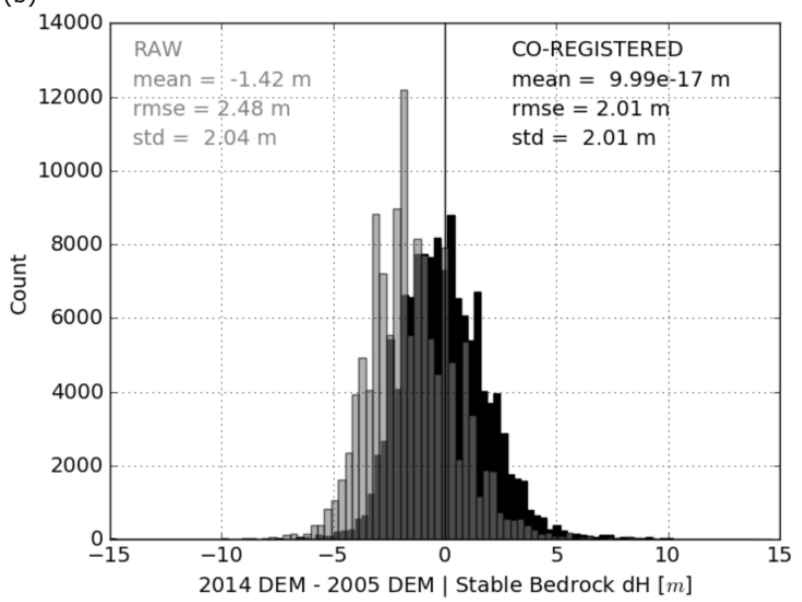

5 Figure S2: Elevation differences over stable bedrock terrain before (gray bars) and after (black bars) co-registration of the (a) 1960/2005 and (b) 2005/2014 DEMs. Plots show the magnitude (x-axis) and pixel count (y-axis) of elevation differences over stable bedrock terrain that is low-sloping $\left(<30^{\circ}\right)$, and free of vegetation, snow, and ice. Text on the plots reports mean, root mean square error (rmse), and standard deviation (std) of these elevation differences for the raw (gray text) and coregistered (black text) results. The number of pixels used for co-registration for 1960/2005 ( $n=23,951)$ was fewer than for

$102005 / 2014(n=127,440)$ due to the 2005 and 2014 DEMs covering more bedrock terrain. Dark gray bars are an artefact of light gray bar transparency. 
(a)

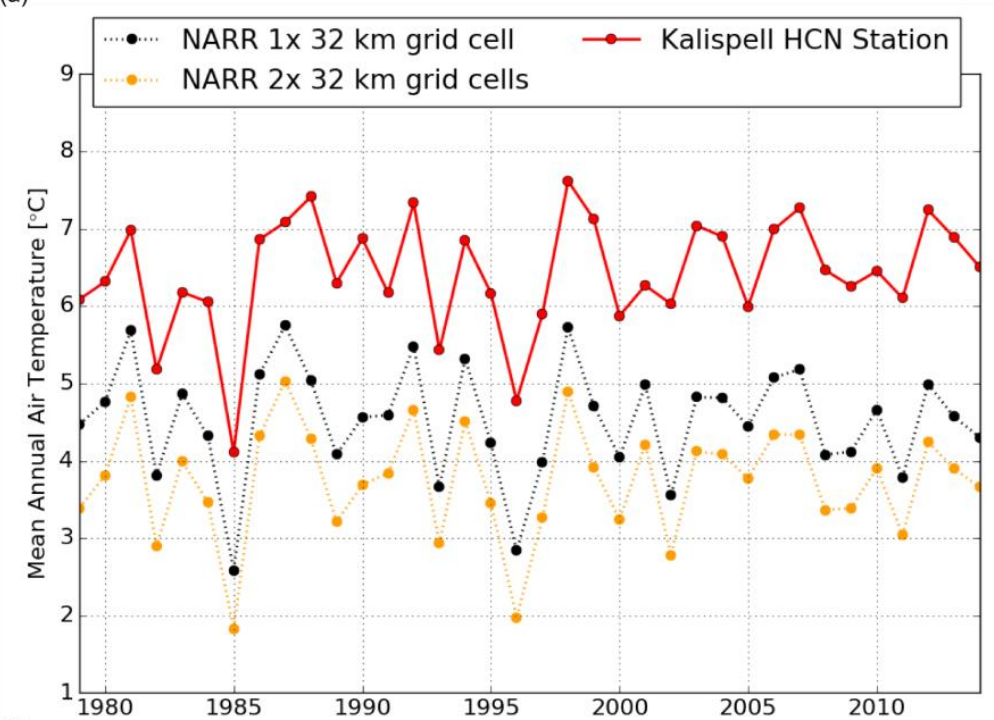

(b)

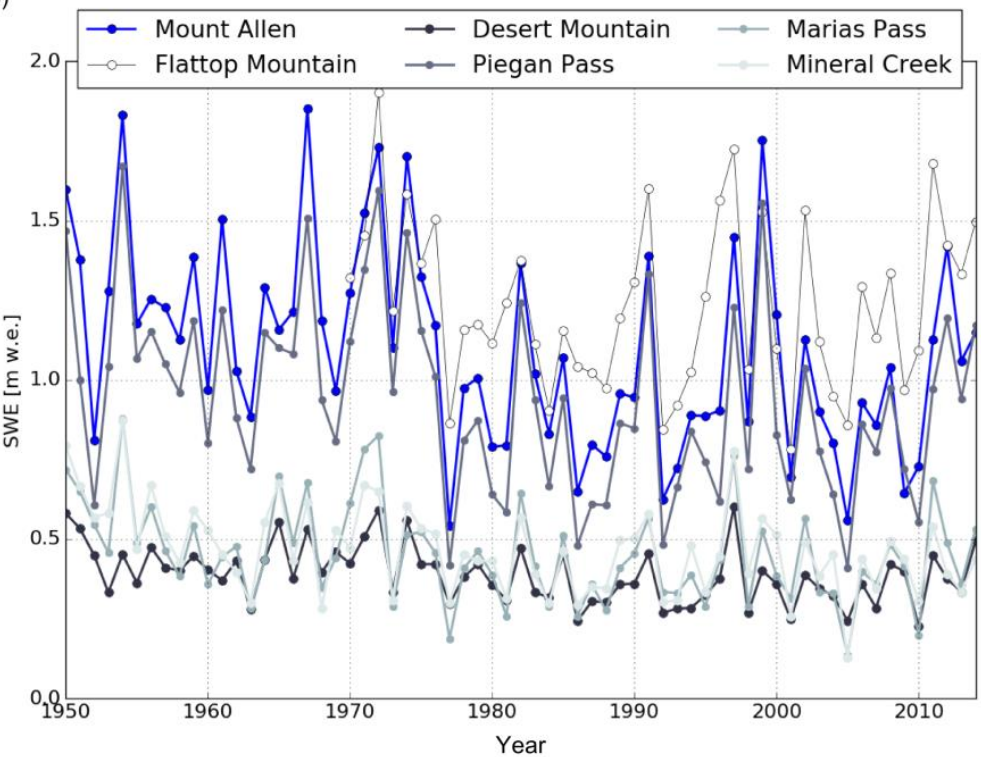

Figure S3: Auxiliary meteorological and snow data. (a) Mean annual air temperatures measured (solid lines) at the Kalispell Historical Climate Network $(\mathrm{HCN})$ station (red) compared with mean annual air temperatures according to North American

5 Regional Reanalysis output (dotted lines) for a single 32-km grid cell containing the Kalispell station (black), and two 32-km grid cells containing the Kalispell station and Sperry Glacier (yellow). (b) Annual peak SWE data for six snow stations in the study area. Station details listed in Table S3. 
Table S1: Digital elevation model (DEM) results for the truncated glacier. Differences from the full glacier results (see Table 2), where 2014 elevations were used to fill in the missing upper section, are also reported.

\begin{tabular}{|c|c|c|c|c|c|c|}
\hline & \multirow{2}{*}{$\begin{array}{c}\text { Area } \\
\left(\mathrm{m}^{2} \times 10^{6}\right)\end{array}$} & \multicolumn{2}{|c|}{ Difference from Full Glacier Results } & \multirow{2}{*}{$\begin{array}{l}\text { Median Elevation } \\
\text { (m a.s.l.) }\end{array}$} & \multicolumn{2}{|c|}{ Difference from Full Glacier Results } \\
\hline & & $\left(m^{2} \times 10^{6}\right)$ & (\%) & & (m a.s.l.) & (\%) \\
\hline $1950 \mathrm{DEM}$ & 1.16 & -0.14 & -11 & 2305 & -12 & -0.5 \\
\hline 1960 DEM & 1.10 & -0.13 & -12 & 2310 & -15 & -0.7 \\
\hline
\end{tabular}


Table S2: Geodetic mass balance results for the truncated glacier. The net change in volume $(\Delta \mathrm{V})$ and mass $(\Delta \mathrm{M})$ are listed, as are mass change rates $\left(\mathrm{dH} \mathrm{dt}^{-1}\right)$. Differences from full glacier results, where 2005-2014 values were used to fill in the missing upper section, are also reported.

\begin{tabular}{|c|c|c|c|c|c|c|c|c|c|}
\hline & $\begin{array}{c}\text { Net } \\
\text { Volume } \\
\text { Change }\end{array}$ & \multicolumn{2}{|c|}{$\begin{array}{l}\text { Difference from Full } \\
\text { Glacier Results }\end{array}$} & \multirow{3}{*}{$\begin{array}{c}\text { Net } \\
\text { Mass } \\
\text { Change } \\
\Delta \mathrm{M} \\
\left(\mathrm{kg} \times 10^{9}\right)\end{array}$} & \multicolumn{2}{|c|}{$\begin{array}{l}\text { Difference from Full } \\
\text { Glacier Results }\end{array}$} & \multirow{2}{*}{$\begin{array}{c}\text { Mass } \\
\text { Change } \\
\text { Rate } \\
\mathrm{dH} \mathrm{dt}^{-1}\end{array}$} & \multicolumn{2}{|c|}{$\begin{array}{l}\text { Difference from Full } \\
\text { Glacier Results }\end{array}$} \\
\hline & $\Delta \mathrm{V}$ & & & & & & & & \\
\hline & $\left(\mathrm{m}^{3} \times 10^{6}\right)$ & $\left(\mathrm{m}^{3} \times 10^{6}\right)$ & (\%) & & $\left(\mathrm{kg} \times 10^{9}\right)$ & (\%) & $\left(m\right.$ w.e. $\mathrm{yr}^{-1}$ ) & $\left(\mathrm{m}\right.$ w.e. $\left.\mathrm{yr}^{-1}\right)$ & (\%) \\
\hline $1950-1960$ & -3.54 & -0.21 & -6 & -3.00 & -0.17 & -6 & -0.26 & -0.04 & -18 \\
\hline $1960-2005$ & -12.3 & -1.00 & -9 & -10.5 & -0.82 & -9 & -0.21 & -0.03 & -17 \\
\hline
\end{tabular}


Table S3: Snow data that were assessed, but not used in the linear regression. The type of snow measurement site and correlation coefficients $\left(\mathrm{r}^{2}\right)$ between glaciological winter mass balance and peak SWE measured at the snow measurement site for 2005-2014 are listed. Winter proportionality factors $\left(m_{w}\right)$, calculated using 2005-2014 glaciological winter balance data; map distance from Sperry Glacier, snow measurement site elevation, and start of the historical record of the snow data 5 (First Year) are also listed. The dash (-) indicates not measured.

\begin{tabular}{|c|c|c|c|c|c|c|}
\hline Site & Measurement & $r^{2}$ & $\begin{array}{c}m_{w} \\
\text { (unitless) }\end{array}$ & $\begin{array}{c}\text { Distance } \\
\text { (km) }\end{array}$ & $\begin{array}{c}\text { Elevation } \\
\text { (m) }\end{array}$ & First Year \\
\hline Sperry Glacier & - & 1 & 1 & 0 & 2450 & - \\
\hline Flattop Mountain & SNOTEL & 0.990 & 2.32 & $\sim 15$ & 1920 & 1970 \\
\hline Mount Allen & Snow Course & 0.973 & 2.99 & $\sim 14$ & 1737 & 1922 \\
\hline Desert Mountain & Snow Course & 0.960 & 7.93 & $\sim 27$ & 1707 & 1937 \\
\hline Piegan Pass & Snow Course & 0.959 & 3.28 & $\sim 14$ & 1676 & 1922 \\
\hline Marias Pass & Snow Course & 0.939 & 6.68 & $\sim 46$ & 1600 & 1934 \\
\hline Mineral Creek & Snow Course & 0.945 & 7.24 & $\sim 13$ & 1219 & 1939 \\
\hline
\end{tabular}

